\title{
Microbial Population Dynamics and Composition in Crude Oil Contaminated Soils Treated with Microorganisms and Guinea Grass (Panicum maximum)
}

\author{
Benwari, A. O.* Kamalu, O. J. \\ Department of Crop and Soil Science, Faculty of Agriculture. University of Port Harcourt, Rivers State, Nigeria
}

\begin{abstract}
Crude oil pollution can cause alterations in the soil physico- chemical properties and microbial activities, with deleterious effects on soil productivity indices. Studies were conducted on a sandy loam soil contaminated with levels of crude oil, bioremediated with bacteria, fungi and guinea grass. The experiment was a $3 \times 4$ factorial in completely randomized design (CRD) in the screen house in the University of Port Harcourt. Results showed that all the treatments had significant $(\mathrm{p}<0.05)$ effects on microbial population, diversity and total petroleum hydrocarbons (TPHs). Bacteria significantly $(\mathrm{p}<0.05)$ reduced TPH within 6 to 8 days. Bacillus Streptococcus, Staphylococcus, Aermonnas and Pseaudomanas spp. were the dominant bacteria found in the soil whereas, Aspergillus, Fusarium, Rhizopus, Blastomycetes and Saccharomyteces species were the dominant fungi isolates. Guinea grass was not effective in bioremediation when the crude oil was above $5 \% \mathrm{w} / \mathrm{w}$ level of contamination. Keywords: Crude oil, bioremediation, bacteria, fungi, soil fertility, petroleum hydrocarbon.
\end{abstract}

DOI: $10.7176 / \mathrm{JBAH} / 9-16-01$

Publication date: August $31^{\text {st }} 2019$

\section{Introduction}

Soil contamination with petroleum and petroleum based products is a major concern to humans and the ecosystem indicators including farmlands, crop plants and forest trees species (Ogari, 2001; Agbogidi, 2003). Most often, the problems of crude oil pollution occur as a result of accidental discharge, seepage, loading and offloading and improper disposal (Njoku et al., 2009). The amount of contamination due to natural seepage is estimated at 600,000 metric tons per year, with arrange of uncertain components of about 200,000 metric tons (Kvenolden and Cooper, 2003). High content of hydrocarbons and certain hazardous compounds in relatively high concentrations in crude oil has also been reported to affect soil physical, chemical and biological properties (Franco et al., 2004). On the other hand, diverse microorganisms such as bacteria, fungi, algae, viruses, and protozoa form biological phase (Tanee and Albert, 2011) and they play vital roles as ecosystem indicators, including nutrient cycling (Zucchi et al., 2003). They are responsible for decomposition of organic matter (Wolicka et al., 2009), which invariably promote plant health and growth as bio fertilization (Liu et al., 2008), and aid in bio remediation processes.

Degradation of petroleum hydrocarbon by natural population of microorganisms is the main process acting in the cleanup of hydrocarbons. In situ degradation involves greater degradation of oil pollutants on site by a consortium of microorganisms (Ojumu et al., 2004) and more than 200 species of bacteria, fungi and algae can biodegrade hydrocarbons. Various genera of these organisms are hydrocarbon degrading species such as Bacillus, Arthrobacter, Pseudomonas, Staphylococcus, Aeromonas, Flarobacterium, Aspergillus, Fasarium and have been isolated in large numbers from many polluted waters and soils (Okoh, 2003).

Although, there are several studies to show that microorganism can remediate crude oil polluted soils, there is still need to study the effect of crude oil pollutions at different concentrations on the growth, distributions and diversity of soil microorganisms. The aim of this study therefore is to determine the microbial population dynamics and composition with varying levels of crude oil pollution in a sandy loam soil in Ibaa community, Emohua local government of Rivers State.

\section{Materials and Methods}

Study Area and Sample Collection: Surface soil samples $(0-20 \mathrm{~cm})$ was collected from Ibaa community in Emohua Local Government Area of River State, Nigeria. The sampled site is located at Latitude $04^{\circ} 57^{\prime} \mathrm{N}$, and Longitude $6^{\circ} 48^{\prime} \mathrm{E}$. the soil was taken to the screen house at the Faculty of Agriculture, Department of Crop and Soil Science, University of Port Harcourt, River State, Nigeria for the simulation study. The mean annual rainfall of the area ranged between $2000 \mathrm{~mm}$ and $45000 \mathrm{~mm}$ with peak periods in July and October (Inyang, 1978). The annual temperature ranged from a minimum of $22^{\circ} \mathrm{C}$ to a maximum of $31^{\circ} \mathrm{C}$.

Experimental procedure and Soil Treatment: Crude oil was obtained from the Shell Petroleum Company Nigeria in Rivers State and used to contaminate the soil at $0,2,5$, and $10 \% \mathrm{w} / \mathrm{w}$ levels of contamination. Six kilogram $(6 \mathrm{~kg})$ of the soils was filled in experimental pots and further treated with Fungi, Bacteria and guinea grass. The experiment was a $4 \times 3$ factorial, arranged in completely randomized design (CRD) in 3 replications. 
Treatment combinations are shown in Table 1. Initial properties of composite soil samples used for the experiment are shown in Table 2. In treating the soils, the methods of Njoku et al., (2009) were used by thoroughly mixing the crude oil with soils. The experiment commenced in late August to October, 2018 (8 weeks).

Isolation of Total Heterotrophic Bacteria THB): Total heterotrophic bacterial counts were determined using the serial dilutions and spread plate technique on nutrient agar as described by Fawole et al. (2001). The colony forming units (cfus) were counted after incubating the samples at $37^{\circ} \mathrm{C}$ for $24 \mathrm{~h}$. transferred onto agar slant for storage. Identification of isolations was one by biochemical test as described in Bergey's manual to determine bacteriology.

Isolation of Total Heterotrophic Fungi (THF): Total heterotrophic fungi count was determined using serial dilution and spread plate technique on potato dextrose agar methods as described by Monica (2001). The soil samples were prepared by 10 fold serial dilutions of 103 dilutions and incubated at room temperature of $25^{\circ} \mathrm{C}$ for 5 days. Pure fungal isolates were identified using lacto phenol blue and direct microscopy (Monica, 2001).

Table 1. Treatment Combinations

\begin{tabular}{ll}
\hline Treatments & Designation \\
\hline $\mathrm{C}$ & Control \\
$\mathrm{B}$ & Bacteria alone \\
$\mathrm{F}$ & Fungi alone \\
$\mathrm{G}$ & Guinea grass alone \\
$\mathrm{BCu}_{2}$ & Bacteria and $2 \%$ crude oil \\
$\mathrm{FCu}_{2}$ & Fungi and $2 \%$ crude oil \\
$\mathrm{GCu}_{2}$ & Guinea grass and $2 \%$ crude oil \\
$\mathrm{BCu}_{5}$ & Bacteria and $5 \%$ crude oil \\
$\mathrm{FCu}_{5}$ & Fungi and $5 \%$ crude oil \\
$\mathrm{GCu}_{5}$ & Guinea grass and $5 \%$ crude oil \\
$\mathrm{BCu}_{10}$ & Bacteria and $10 \%$ crude oil \\
$\mathrm{FCu}_{10}$ & Fungi and $10 \%$ crude oil \\
$\mathrm{GCu}_{10}$ & Guinea grass and $10 \%$ crude oil
\end{tabular}

Isolation of Hydro Carbon Utilizing Bacteria and Fungi and Total Petroleum Hydrocarbon One gram of each soil sample was diluted serially $10^{-1}$ to $10^{-7}$ in triplicates and inoculated in minerals salt agar, using the spread plate technique. Colonies of hydrocarbon utilizing bacteria and fungi were randomly obtained using potatoe dextrose. Identification was done using biochemical test described in Bergey's Manual. Total petroleum hydrocarbon content was measured using the method of cold extraction method as described by Odu et al. 1995 . The total petroleum hydrocarbon (TPH) concentrations in the samples were determined using the stored calibration curve.

Determinations of Particle-size Distribution, pH and Organic Matter: Particle size distribution was determined by the method of Gee and Bauder (1986) after soil dispersion with sodium hexametaphosphate. Soil $\mathrm{pH}$ was measured with a glass electrode in a 1:2.5 soil water solution (McLean, 1982). Total organic carbon was determined by Walkley and Black wet dichromate oxidation method (Nelson and Sommers, 1996).

Data Analysis: A two-way analysis of variance was carried out using the SAS software (SAS, 2001), and the least significant difference (LSD) of the treatment means was determined at $5 \%$ probability.

\section{Results and Discussion}

The soil is sandy loam with sand, silt and clay content are 75.2, 2.3, and 21.5\% respectively (Table 1), and slightly acidic $(\mathrm{pH}$ 6.2). Total nitrogen and organic carbon were low, indicating low fertility status of the soil. Total petroleum hydrocarbon was near threshold value of Odu et al. (1995) for sandy loam soils of the Niger Delta. Total heterotrophic bacteria and fungi were low $\left(270\right.$ and $12 \times 10^{3} \mathrm{cfus} \mathrm{g}^{-1}$, respectively. 
Table2: Initial soil properties before contamination

\begin{tabular}{ll}
\hline Soil Properties & Mean value \\
\hline $\mathrm{pH}$ & 6.2 \\
Total petroleum hydrocarbon $\left(\mathrm{mg} \mathrm{kg}^{-1}\right)$ & 1578.95 \\
Sand $(\%)$ & 75.2 \\
Salt $(\%)$ & 2.3 \\
Clay $(\%)$ & 21.5 \\
Texture & $\mathrm{SL}$ \\
TOC $(\%)$ & 0.91 \\
Total N (\%) & 0.046 \\
Available P $\left(\mathrm{mg} \mathrm{kg}^{-1}\right)$ & 8.50 \\
Total heterotrophic bacteria $\left(\mathrm{x} 10^{3} \mathrm{cfus} \mathrm{g}^{-1}\right)$ & 270 \\
Total heterotrophic fungi $\left(\mathrm{x} 10^{3} \mathrm{cfus} \mathrm{g}^{-1}\right)$ & 12 \\
\hline TOC-
\end{tabular}

TOC- total organic carbon, SL- sandy loam

Effect of Treatments on Total Petroleum Hydrocarbons and Soil pH: Changes in total petroleum hydrocarbon (TPH) and $\mathrm{pH}$ are shown in Table 3. Guinea grass was not effective in reducing TPH compared to fungi treated soils. Total petroleum hydrocarbon $(\mathrm{TPH})$ ranged from 11457.2 in fungi treated soils to 1676.8 for guinea grass soils. When heavy load of crude oil $(5 \%$ and $10 \%)$, fungi consistently showed positive $(p<0.05)$ effect in degrading TPH. On the other hand, fungi tend to increased soil acidity. For example, $\mathrm{pH}$ was 5.3, 5.8 and 5.9 for $\mathrm{F}, \mathrm{FCu}_{5}$ and $\mathrm{FCu}_{10}$, respectively, compared with bacteria which increased soil $\mathrm{pH}$ significantly $(p<0.05)$. This implied that bacteria modified soil acidity to a minimum. This is consistent with previous works by Nester et al. (2001) and Okoh (2006) that bacteria modified the soil temperature and consequently, soil pH to favour biodegradation. The use of fungi in bioremediation process led to significant increase in soil $\mathrm{pH}$, whereas, guinea grass did not show significant short-term effect in removal of TPH.

Effects of Treatments on Hydrocarbon Utilizing Bacteria and Fungi: Hydrocarbon utilizing bacteria didn't show any significant difference with the treatments applied until four weeks after planting (4 WAP), where the bacteria population was highest $\left(540.50\right.$ Cfus $\left.\times 10^{3} \mathrm{~g}\right)$ at $0 \%$ and significantly reduced to the lowest $(372.00 \mathrm{Cfus}$ $\times 10^{3} \mathrm{~g}$ ) level at $10 \%$ load of crude oil at $\mathrm{P} \leq 0.05$ (Table 4). The treatments had significant influence on the hydrocarbon utilizing fungi across the period of assessment with the fungi population increasing with increase in weeks after application. At 2 WAP, a sharp fall was noticed in the population of fungi at $2 \%$ treatment level before the population began to increase with increase in the levels of treatment, while at 4 WAP, the hydrocarbon utilizing fungi significantly increased with a rise in the treatment levels at $\mathrm{P}<0.05$. This is consistent with the report of Agbobidi et al. (2005), that hydrocarbon utilizing micro-organisms usually increased during the early period of introduction of petroleum hydrocarbon and reduced to minimum after a long period as observed at 8 weeks after application (8 WAA).

Percent Occurrence of Heterotrophic and Hydrocarbon Utilizing Bacteria and Fungi: Bacillus and Aspergilus were found to be more populated when compared to other bacteria and fungi isolates in both the treated and non-treated soils (Table 5). Bacillus and Aspergilus species were consistently found in all the samples showing adaptability of the two species. On the other hand, the pseudomonas were inhibited in the contaminated soils, indicating that pseudomonas do not grow in crude oil contaminated environment. The result is consistence with the previous assertions of Santhoshkumar et al. (2015) who identified Bacillus subitilis, and insignificant numbers of Pseudomonas putidda, in Chlorpyrifos polluted soil in India. Bacillus and Aspergilus species are well known species in the breakdown of petroleum hydrocarbons in soil. This result further agreed with the findings of Tesar et al. (2002) who reported a broad phylogenetic range of bacteria and fungi including species/strains of Bacillus, Pseudomonas, Areomonas spp, Staphloccocus spp, Streptoccocus spp in contaminated soils

Conclusion: The following revelations were made from this study: Bacillus and Aspergillus species of microorganisms were commonly found in treated soils than in untreated soils. They both have the potential to tolerate and grow in crude oil contaminated soils and can be used in remediation of contaminated soils. Fungi alone were not very effective in bioremediation technology. Bacteria were more effective in cleanup of the crude oil contamination soils above $5 \% \mathrm{w} / \mathrm{w}$, whereas, Guinea grass is recommended in low levels of crude oil contamination. Both the total heterotrophic and hydrocarbon utilizing microorganisms increased significantly during the early 4 to 6 weeks of contamination and reduced significantly at 8 weeks after application (WAA). 
Table 3. Effects of treatment on total hydrocarbon and pH at 8 weeks after application

\begin{tabular}{lll}
\hline Treatments & Total hydrocarbon $\left(\mathrm{mg} \mathrm{kg}^{-1}\right)$ & $\mathrm{pH}\left(\mathrm{H}_{2} \mathrm{O}\right)$ \\
\hline $\mathrm{C}$ & 1672.5 & 6.2 \\
$\mathrm{~B}$ & 1554.8 & 6.8 \\
$\mathrm{~F}$ & 1457.2 & 5.1 \\
$\mathrm{G}$ & 1676.8 & 5.3 \\
$\mathrm{BCu}_{2}$ & 1577.9 & 6.4 \\
$\mathrm{FCu}_{2}$ & 1581.7 & 6.1 \\
$\mathrm{GCu}_{2}$ & 1512.6 & 5.8 \\
$\mathrm{BCu}_{5}$ & 1591.2 & 6.1 \\
$\mathrm{FCu}_{5}$ & 1588.4 & 6.3 \\
$\mathrm{GCu}_{5}$ & 1591.1 & 6.1 \\
$\mathrm{BCu}$ & 6.6 \\
$\mathrm{FCu}$ & 1622.5 & 5.9 \\
$\mathrm{GCu}$ & 1597.5 & 5.2 \\
$\mathrm{LSD}(0,05)$ & 1623.9 & 1.3 \\
\hline
\end{tabular}

Table 4. Effects of Treatments on Hydrocarbon Utilizing Bacteria and Fungi

\begin{tabular}{|c|c|c|c|c|c|c|}
\hline \multirow[b]{2}{*}{ Treatment } & \multicolumn{3}{|c|}{ Hydrocarbon Utilizing Bacteria (cfus x $10^{3}$ ) } & \multicolumn{3}{|c|}{ Hydrocarbon Utilizing Fungi (cfus x $10^{3}$ ) } \\
\hline & 2 WAA & 4 WAA & 8 WAA & $2 \mathrm{WAA}$ & 4 WAA & 8 WAA \\
\hline $\mathrm{C}$ & 272.8 & 540.5 & 569.8 & 2.30 & 4.28 & 4.36 \\
\hline $\mathrm{BCu}_{0}$ & 252.7 & 412.4 & 569.08 & 2.11 & 5.61 & 6.33 \\
\hline $\mathrm{FCu}_{0}$ & $230 . .2$ & 422.5 & 468.19 & 2.46 & 4.88. & 5.19 \\
\hline $\mathrm{GCu}_{0}$ & 231.5 & 432.8 & 332.18 & 2.39 & 4.22 & 5.125 \\
\hline $\mathrm{BCu}_{2}$ & 236.5 & 436.5 & 411.32 & 2.14 & 4.50 & 6.25 \\
\hline $\mathrm{FCu}_{2}$ & 248.0 & 421.6 & 472.16 & 2.04 & 4.36 & 7.11 \\
\hline $\mathrm{GCu}_{2}$ & 241.5 & 511.7 & 406.52 & 3.71 & 4.11 & 6.0 \\
\hline $\mathrm{BCu}_{5}$ & 257.9 & 484.3 & 426.12 & 3.63 & 6.91 & 6.38 \\
\hline $\mathrm{FCu}_{5}$ & 141.3 & 461.3 & 431.16 & 3.33 & 6.21 & 6.33 \\
\hline $\mathrm{GCu}_{5}$ & 221.9 & 433.7 & 418.22 & 3.49 & 6.66 & 6.48 \\
\hline $\mathrm{BCu}_{10}$ & 195.0 & 372.0 & 303.05 & 3.71 & 7.55 & 7.34 \\
\hline $\mathrm{FCu}_{10}$ & 183.1 & 318.5 & 310.44 & 3.11 & 7.23 & 7.21 \\
\hline $\mathrm{GCu}_{10}$ & 241.6 & 402.1 & 384.55 & 3.59 & 6.49 & 7.09 \\
\hline
\end{tabular}

$\operatorname{LSD}(0.05)$ : Bacteria $=\mathrm{NS}$, Bacteria $\mathrm{x}$ weeks $=31.87$, Fungi $=0.508$, fungi $\mathrm{x}$ weeks $=0.3584$

Table 5. Occurrence of heterotrophic and hydrocarbon utilizing bacteria and fungi at 2 weeks after crude oil application

\begin{tabular}{lllllll}
\hline & \multicolumn{2}{c}{ Occurrence $(\%)$} & & \multicolumn{2}{c}{ Occurrence $(\%)$} \\
\cline { 2 - 3 } Bacteria Isolated & THB & HUB & Fungi Isolated & THF & HUF \\
\hline Bacillus spp & 40 & 45 & Aspergillus spp & 50 & 40 \\
Streptococcus spp & 15 & 10 & Fusarium spp & 2 & 3 \\
Staphylococcus & 30 & 30 & Rhizopus & 35 & 50 \\
Aermonnas spp & 5 & 10 & Blastomycetes & 10 & 5 \\
Pseaudomonas & 5 & 5 & Saccharomyteces & 2 & 2 \\
\hline
\end{tabular}

THB- Total heterotrophic bacteria, HUB- Hydrocarbon utilizing bacteria,

THF- Total heterotrophic fungi, HUF- hydrocarbon utilizing fungi

\section{References}

Agbogidi, O.M. 2003. Response of Azolia Africana Desv. and salivinia nympphellula Desv. to the water soluble fraction of Odidi Well Crude Oil. Journal of Science and Technology Research 2 (4): 76-80.

Agbogidi, O.M; Nweke, F.U. and Eshegbeyi, 0.F. 2005. Effects of soil pollution by crude oil on seedling growth of Leucaena leucocephola (Lam.De Witt). Global Journal of pure and Applied Sciences 11(4): 453-456.

Monica, C. 2005. District laboratory practice in tropical countries 2nd edition pp 62-72.

Nester, E.W., Denise, G.A.C., Evans, R.J., Nancy N.P. and Martha, T.N. 2001. Microbiology: A Human perspective. 3rd ed. New York: MC Gran-Hill.

Njoku, K.L., Akinola, M.O. and Ige, T.O. 2009. Comparative effects of diesel fuel and spent lubricating oil on the growth of Zea mays (maize).American-Eurasian Journal of Sustainable Agriculture, 3(3):428-434.

Ogari, O.R 2001. A Review of the Nigerian Petroleum Industry and the Associated environmental problems. The 
Environmentalist 21 (1):11-21

Okoh, A.I. 2006. Biodegradation alternative in the clean up of petroleum hydrocarbon pollutants. Biotechnology and Molecular Biology Reviews, 1(2), 38-50.

Kvenvolden, K.A. and Copper, C.K 2003. Natural Seepage of Crude oil into Marine Environment. Geo-Marine Letters, 23(3-4), 140-146.

Franco, I.M., Contin, G. Bragaton and M. De Nobili, 2004. Microbiological resilence of soils. Contaminated with crude oil. Geodema, 121:17-30.

Fawole, M.O, Oso, B.A. 2001. Laboratory Manual of Microbiology; Revised edition spectrum broks ltd of Ibadan P.127

Santhosshkumar, M. Mahakavi, T. and Baskaran L. 2015. "Isolation and identification of Bacteria from Chlorpyrifos Polluted Soil". International Letters of Natural Science, Vol. 45, pp 23-26.

Tessar, M., reichenauer, T. G and Sessitsch A. 2002. "Bacterial rhizosphere populations of blank poplar and herbal plantts to be used for phytoremeddiation". J. Soil Boil. Biochem., 2; 34: 1883-1892.

Tanee, F.B.G. and Albert, E. 2011. Post-Remediation Assessment of Crude Oil Polluted Site at Kegbara-Dere Communit,), Gokana L.G.A. of Rivers State, Nigeria. Journal of Bioremediation and Biodegradation, 2:122. doi: 10.4172/2155-6199.1000122

Wolicka, D., Suszek, A., Borkowski, A. and Bielecka, A. 2009. Application of aerobic microorganisms in bioremediation in situ of soil contaminated by petroleum products. Bioresources Technology, 100: 32213227.

Liu, P.G., Whang, L., Yang, M and Cheng, S. 2008. Biodegradation of diesel-contaminated soil: A soilcolumn study. Journal of the Chinese Institute of Chemical Engineers, 39: 419-428

Zucchi, M., Angiolini, L. Borin,1 S., Brusetti, L., Dietrich, N., Gigliotti, C.,Barbieri, P., Sorlini, C., and Daffonchio, D. 2003. Response of bacterial community during bioremediation of an oil-polluted soil. Journal of Applied Microbiology. 94: 248-257.

Ojumu, T.V., Yu, J. and Solomon, B.O. 2004. Production of Polyhydroxyalkanoates, a bacterial biodegradable polymer. African Journal of Biotechnology, 3:18-24.

Gee, G.W. and Bauder, J.W., 1986. Particle-size analysis. In: Klute, A. (Ed.), Methods of Soil Analysis. ASA and SSSA, Madison, WI, USA, pp. 383-411.

Nelson, D.W.and Sommers. L.C. 1996.. Total Carbon, Organic Carbon, and Organic Matter. In Sparks, D.L. (ed.). Methods of Soil Analysis. Part 3. Chemical Methods. SSSA, Madison, W.I. USA., pp 539-579.

Mclean EO. 1982. Soil $\mathrm{pH}$ and lime requirement. In 'Methods of soil analysis. Part 2: Chemical and microbiological properties. Agron. Monograph No. 9. 2nd ed. (Eds AL Page, RH Miller, DR Keeney) Amer. Soc. Agron. Madison, WI, USA., pp. 595-624.

Odu, C. T. L., Nwoboshi, L. C., Fagage, S. O. and Awani, P. E. 1995. Post - Impact study of SPDC's Nun River 8 Delivering line oil spillage (pp. 5-9). Final Report, SPDC. Nig.

Inyang, P. E. B. 1978. Climate regime. In G. R. K. Ofomata (Ed.), Nigeria in Maps. Eastern States (pp. 2-27). Ethiopia Publ. House. Benin City, Nigeria.

SAS- Statistical Analysis System. Institute. 2001. SAS/STAT User's Guide. 4th Edition, Version 6, SAS Institute. Cary, NC, USA. 